\title{
DETERMINING X-RAY EFFECTIVE ENERGY IN LINEAR ACCELERATOR (LINAC) RADIOTHERAPY INSTRUMENT
}

\author{
Fauziah*1, Bualkar Abdullah $^{2}$ \\ ${ }^{1,2}$ Physics Department, Hasanuddin University Perintis Kemerdekaan Street, Km.10, Tamalanrea Indah, \\ Tamalanrea, Makassar, North Sulawesi, Indonesia \\ *Correspondence address: hidayatfauziah70@gmail.com
}

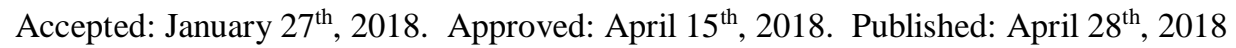

\begin{abstract}
This research in determining $x$-ray effective energy in linear accelerator (Linac) radiotherapy device was done using copper plates at different thicknesses by determining the Half Value Layer (HVL) for each energy. The purpose of this research is to know the amount of effective energy used in radiotherapy linear accelerator. The results showed that the energy of $6 \mathrm{MeV}$ obtained 2,714 MeV of effective energy at HVL 4,500 mm and at the energy of $10 \mathrm{MeV}$ obtained 4,231 MeV of effective energy at HVL 4,500 $\mathrm{mm}$.
\end{abstract}

(C) 2018 Physics Education Department, UIN Raden Intan, Lampung.

Keywords: copper plates, effective energy, half value layer, linear accelerator

\section{INTRODUCTION}

Radiotherapy in the medical world is a medical instrument which existence is very important. By using radiotherapy device, treatment of cancer patients can be done without causing damage to normal tissue. the use of radiotherapy should be optimized at the target volume in regard to the effective dose received by without causing significant damage to the surrounding normal tissue (G. \& Budiantari, 2005). Therefore, routine patient doses should be performed. Thus, it is expected to obtain local control, prolong life expectancy, and maintain the quality of life (Fahmi, Arif, Firdausi, \& Budi, 2008).

One of the important parameters in $\mathrm{X}$ rays to be controlled is the quality of the $\mathrm{X}$ ray beam. The quality of the $\mathrm{X}$-ray beam is expressed in the amount of Half Value Layer (HVL) or the thickness of the material, i.e. the size of the penetrating power of X-rays penetrating the material until its intensity is halved that of the original. The greater the HVL value the greater the translucency, and vice versa (Yunita, Setiawati, \& Anam, 2014), determining HVL value with a single expose is, of course very practical and efficient. However, it should be noted that a practical and efficient system is not enough. Moreover, the system must be accurate (Yunita et al., 2014).

In Indonesia, the Decree of the Minister of Health of the Republic of Indonesia number 1250, the Half Value Layer (HVL) or Partial Thickness Value is one of the parameters specified and is part of the generator testing becomes an element of the X-ray generator system. The inconsistency of production / X-ray output from the X-ray tube generated by a generator is strongly influenced by technical parameters such as tube voltage quality, current strength and time (Peraturan Pemerintah Republik Indonesia, 2009). The amount of inconsistent radiation output due to a poor performance of technical parameters directly affects the variations in the quality of the picture, the quality or quantity of radiation produced and the radiation dose that occurs. It is therefore important to monitor HVL parameters due to the increased effective energy of X-rays and indirectly improve 
the performance of X-ray instrument so that the quality of radiographs in providing clear information about the objects or organs examined will be better (Yunita, Evi Choirul, 2014).

The quality of the $\mathrm{x}$-ray beam is necessary to know to achieve the diagnostic purpose, which can be read and analyzed properly and accurately by the doctor and minimize the dose received by the patient (Sumarni \& Mart, 2000) as, the research has been done with the title of determining $\mathrm{x}$-ray effective value on the radiodiagnostic instrument, the study was conducted by measuring the effective value of radio diagnostic instrument. Given the current health check do not only rely on the radio diagnostic instrument, thus this research was done in determining the effective value by using radiotherapy instrument.

Determining the HVL or X-ray instrument can be done by using the variation of filter thickness and using X-ray multimeter tool (Palinggi, 2016). Investigated the determination of $\mathrm{HVL}$ values using filter thickness variation on Linear Accelerator (LINAC) instrument, the purpose of the research was to determine the HVL value of LINAC radiotherapy instrument with filter thickness variation, determine the thickness of the filter used to obtain HVL, and determine the value of the linear attenuation coefficient $(\mu \mathrm{l})$ of the filter used, so that the HVL value of the energy of $6 \mathrm{MV}$ is $3.85 \mathrm{~cm}$, while the HVL value of the energy of $10 \mathrm{MV}$ is $5.95 \mathrm{~cm}$. The hydroperformation of the electrode $(\mu)$ of the aluminum filter at the energy of $6 \mathrm{MV}$ is $u 0.18 \mathrm{~cm}-1$ while the energy of $10 \mathrm{MV}$ is $0.107 \mathrm{~cm}-1$.

\section{THEORY}

Half Value Layer (HVL) is the thickness of the material required to reduce the intensity of X-rays to half of the original intensity. The advantages of using HVL are increasing the effective energy of
X-rays and indirectly improving the performance of X-ray instrument. If the effective energy of the X-ray beam increases because of the increase in effective energy due to the addition of the filter, the X-ray penetration is also increased (Sprawls, 1995).

The Half-value layer is the thickness required to absorb the radiation of its intensity to half $\left(I_{x}\right)$ of the initial intensity $\left(I_{0}\right)$. In general, $I_{x}$ value can be written (Nurdin, 2015).

$$
I_{x}=I_{0} / 2
$$

X-ray beam that penetrates the material, in this case, the body, will be attenuated so as to reduce the $\mathrm{x}$-rays output. It can be seen in the following equation

$\mathrm{I}=\mathrm{I}_{0} \mathrm{e}^{-\mu \mathrm{x}}$

With I as the intensity of the forwarded photon, $\mathrm{I}_{0}$ is the intensity of the coming photon, and $\mu$ as the coefficient of linear attenuation, whereas $x$ is the thickness of the material. All of the above variables can be measured except $\mu$ (Gabriel, 1996).

By defining the HVL value, we can obtain the relationship between HVL with linear attenuation coefficient and can be written:

$$
I_{x}=I_{0} \exp (-\mu x)
$$

Where $I_{x}$ is the intensity obtained after the radiation passes through the material with the thickness of $x, I_{0}$ is the initial radiation intensity and $\mu$ is the linear attenuation coefficient of the material used (Nurdin, 2015).

The linear attenuation coefficient $(\mu)$ is the smallest fraction of the intensity of the photon beam lost on each unit of material thickness, in which case $\mathrm{cm}$. the value of $\mu$ is determined by the large cross section of each interaction process that occurs (Sumarni, 2008). 


\section{METHOD}

\section{Tools and Materials}

1. Linear Accelerator radiotherapy instrument.

Linear Accelerator radiotherapy instrument serves as an X-ray generator.

2. Four pieces of copper filters with the thickness of $0.1 \mathrm{~mm} ; 0.5 \mathrm{~mm} ; 1 \mathrm{~mm}$; and $2 \mathrm{~mm}$.

Copper filters are used as the test material to determine the $\mathrm{x}$-ray beam of the radiotherapy instrument.

3. Survey Meter.

Survey meter serves as a detector measuring the value of exposure to radiation released by radiotherapy instrument.

4. Meter.

The meter serves as a measurement for the distance between the radiotherapy instrument to the detector.

\section{Research Procedure}

1. preparing survey meters and copper plates

2. Preparing radiotherapy instrument in ready-made condition

3. Adjusting the position of radiotherapy and survey meter instrument

4. Adjusting the voltage on the radiotherapy instrument

5. Conducting irradiation

a. Without using any copper filter

b. Using a copper filter with the thickness of $0.2 \mathrm{~cm}$

c. Using a copper filter with the thickness of $0.4 \mathrm{~cm}$

d. Using a copper filter with the thickness of $0.6 \mathrm{~cm}$

e. Using a copper filter with the thickness of $0.8 \mathrm{~cm}$

f. Recording the value obtained from each irradiation

g. Repeat steps a, b, c, d, and e with varying voltages

$h$. Record the results obtained

\section{RESULTS AND DISCUSSION}

In this research, the result of measurement of the average value of the count by using phantom solid water and copper plates of varying thickness was obtained.

Table 1. Measurement Results For $6 \mathrm{MeV}$ Energy

\begin{tabular}{clllllll}
\hline $\begin{array}{c}\text { Plate } \\
(\mathbf{m m})\end{array}$ & I & II & III & IV & V & VI & Mean \\
\hline 0 & 5,54 & 5,51 & 5,55 & 5,41 & 5,52 & 5,53 & 5,51 \\
1,00 & 4,10 & 4,12 & 4,13 & 4,10 & 4,12 & 4,11 & 4,11 \\
1,50 & 3,87 & 3,82 & 3,79 & 3,84 & 3,74 & 3,86 & 3,82 \\
2,50 & 3,55 & 3,60 & 3,64 & 3,56 & 3,54 & 3,55 & 3,57 \\
3,00 & 3,01 & 3,13 & 3,10 & 3,02 & 3,16 & 3,03 & 3,08 \\
4,50 & 2,79 & 2,64 & 2,70 & 2,78 & 2,65 & 2,70 & 2,71 \\
5,15 & 1,45 & 1,52 & 1,48 & 1,47 & 1,50 & 1,48 & 1,48 \\
\hline
\end{tabular}

In table 1 , the result of measurement of exposure by using $6 \mathrm{MeV}$ of energy and copper plates with varying thickness. From table 1, it can be seen that the value obtained was smaller if the copper plate used was thicker, this was due to the thicker the copper plates then the passing energy was also getting smaller

Table 2. Measurement Results For $10 \mathrm{MeV}$ Energy

\begin{tabular}{clllllll}
\hline $\begin{array}{c}\text { Plate } \\
(\mathbf{m m})\end{array}$ & $\mathbf{I}$ & II & Count $(\mathbf{M I I}$ & $\mathbf{I V}$ & V & VI & \multirow{2}{*}{ Mean } \\
\hline 0 & 8,37 & 8,37 & 8,25 & 8,37 & 8,29 & 8,38 & 8,34 \\
1,00 & 7,13 & 7,20 & 7,14 & 7,19 & 7,17 & 7,16 & 7,17 \\
1,50 & 6,51 & 6,57 & 6,53 & 6,48 & 6,53 & 6,52 & 6,52 \\
2,50 & 5,81 & 5,74 & 5,86 & 5,78 & 5,87 & 5,85 & 5,82 \\
3,00 & 5,21 & 5,17 & 5,20 & 5,22 & 5,18 & 5,26 & 5,21 \\
4,50 & 4,30 & 4,20 & 4,21 & 4,22 & 4,21 & 4,22 & 4,23 \\
5,15 & 2,69 & 2,72 & 2,67 & 2,70 & 2,72 & 2,70 & 2,70 \\
\hline
\end{tabular}

In table 2, the result of measurement of exposure by using $10 \mathrm{MeV}$ of energy and copper plates with varying thickness. From table 1 , it can be seen that the value obtained was smaller if the copper plate used was thicker, this was due to the thicker the copper plates then the passing energy was also getting smaller. 
Table 3. Calculation of Energy Intensity for 6 $\mathrm{MeV}$

\begin{tabular}{llll}
\hline $\begin{array}{l}\text { Plate } \\
(\mathbf{m m})\end{array}$ & $\begin{array}{l}\text { Energy } \\
(\mathbf{M e V})\end{array}$ & $\begin{array}{l}\text { Intensity } \\
\left(\mathbf{W} / \mathbf{m}^{\mathbf{2}}\right) \\
\left(\times \mathbf{1 0}^{-\mathbf{2 1}}\right)\end{array}$ & $\mathbf{L n}$ \\
No plate & 5,514 & 2,444 & $-47,460$ \\
1,00 & 4,117 & 1,825 & $-47,752$ \\
1,50 & 3,824 & 1,694 & $-47,827$ \\
2,50 & 3,577 & 1,585 & $-47,893$ \\
3,00 & 3,080 & 1,365 & $-48,043$ \\
4,50 & 2,714 & 1,202 & $-48,170$ \\
5,15 & 1,489 & 0,660 & $-48,769$ \\
\hline \multicolumn{5}{c}{ In table 3, we get the intensity value }
\end{tabular}
for each measurement at $6 \mathrm{MeV}$ energy setting. This intensity value was obtained by finding the relationship between $(\mathrm{MeV})$ with intensity (W / $\mathrm{m} 2$ ) for the measurement without using any copper plate hence greater energy was obtained, this was because there was no shield that blocks out the beam.

Table 4. Calculation of Energy Intensity for 10 $\mathrm{MeV}$

\begin{tabular}{|c|c|c|c|}
\hline $\begin{array}{l}\text { Plate } \\
(\mathbf{m m})\end{array}$ & $\begin{array}{c}\text { Energy } \\
(\mathrm{MeV})\end{array}$ & $\begin{array}{c}\text { Intensity } \\
\left(\mathrm{W} / \mathbf{m}^{2}\right) \\
\left(\times \mathbf{1 0}^{-\mathbf{2 1}}\right)\end{array}$ & Ln \\
\hline 0 & 5,514 & 3,699 & $-47,046$ \\
\hline 1,000 & 4,117 & 3,179 & $-47,197$ \\
\hline 1,500 & 3,824 & 2,894 & $-47,291$ \\
\hline 2,500 & 3,577 & 2,582 & $-47,405$ \\
\hline 3,000 & 3,080 & 2,310 & $-47,517$ \\
\hline 4,500 & 2,714 & 1,875 & $-47,725$ \\
\hline 5,150 & 1,489 & 1,197 & $-48,174$ \\
\hline
\end{tabular}

In table 4 , we get the intensity value for each measurement at $10 \mathrm{MeV}$ energy setting. This intensity value was obtained by finding the relationship between $(\mathrm{MeV})$ with intensity $\left(\mathrm{W} / \mathrm{m}^{2}\right)$ for the measurement without using any copper plate hence greater energy was obtained, this was because there was no shield that blocks out the beam.

Comparison Charts and the thickness of the Copper Plates is shown in Figure 1 below.

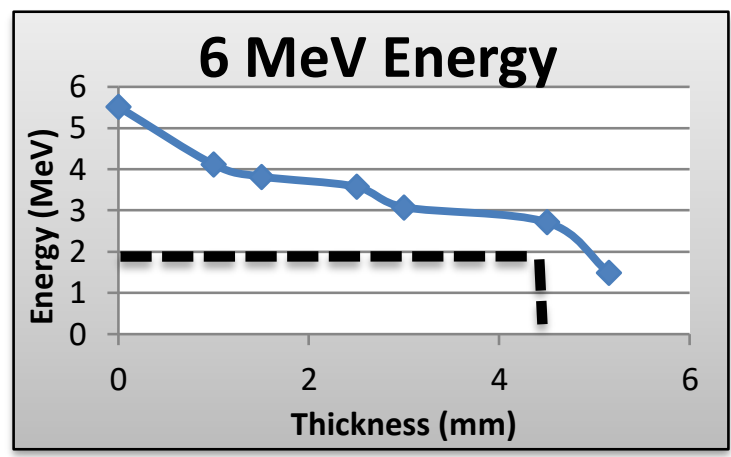

Figure 1. Graph of the thickness of the copper plates with the value of $6 \mathrm{MeV}$ energy

The comparison graph between the copper plates' thickness with the value of $10 \mathrm{MeV}$ energy is shown in Figure 2 below:

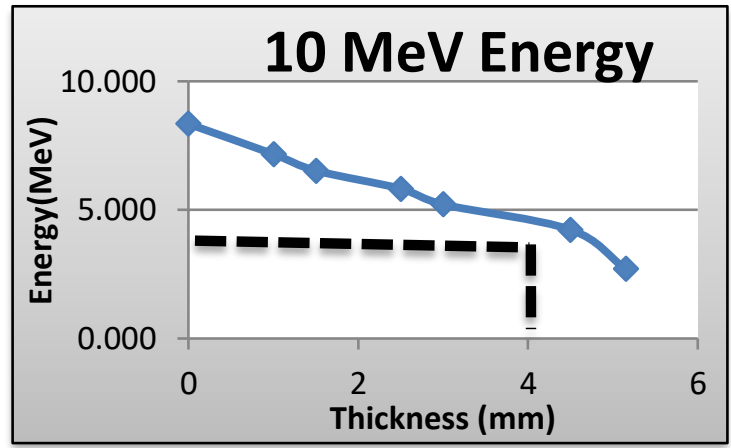

Figure 2. Graph of the thickness of the copper plates with the value of $10 \mathrm{MeV}$ energy

Based on the result of the research, it is known that the thicker the copper plate used, the smaller the count value, the thicker the copper plate used, the greater the radiation exposure. while the measurement without any copper plate, then the amount of radiation exposure will also be greater. As the research was done by Sumarni in 2000 using the plate for determining effective energy. The same research has been done using an aluminum plate (E Ariga, Ito, Deji, Saze, \& Nishizawa, 2012). Research using $\mathrm{Pb}$ shield on Radiotherapy instrument has also been done before that radiation shield was able to inhibit radiation beam output of the radiotherapy instrument where thickness 
will inhibit the amount of radiation beam (Yuniasari, Kristiyanti, Rozali, \& Syawaludin, 2013). This is because the thickness of copper plates influence the exposure to radiation out of the source. the thicker the plate used, the less exposure to radiation that can pass through the plate and vice versa. The thickness of the object affects the quality of the image obtained, the thicker the plate the smaller the intensity and it will also reduce the penetration ability (Sumarni \& Mart, 2000).

In this study, the effective energy of the linear accelerator radiotherapy instrument was obtained when using a copper plate of $4.5 \mathrm{~mm}$ thickness with an energy of $2.714 \mathrm{MeV}$ when the radiotherapy energy was at $6 \mathrm{MeV}$ energy. while the radiotherapy energy was at 10 $\mathrm{MeV}$, energy obtained was $4.231 \mathrm{MeV}$. So it can be concluded that for the use of two energy arrangements that is $6 \mathrm{MeV}$ and 10 $\mathrm{MeV}$ effective energy was obtained when the copper plate with a thickness of $4.5 \mathrm{~mm}$ was used with each energy count of 2.714 $\mathrm{MeV}$ and 4.231 MeV.

\section{CONCLUSION AND SUGGESTION}

\section{Conclusion}

Based on the results of the study, it can be concluded that: The effective energy of linear accelerator radiotherapy instrument using $6 \mathrm{MeV}$ energy setting is $2.714 \mathrm{MeV}$ while using $10 \mathrm{MeV}$ energy setting the energy obtained is $4.231 \mathrm{MeV}$. the effective energy is obtained when a copper plate with $4.500 \mathrm{~mm}$ thickness is used.

\section{Suggestion}

Effective $\mathrm{x}$-ray energy measurements on a linear accelerator radiotherapy instrument should employ more variable energy arrangements not only the two energy settings and the thickness of the plate used should be more varied.

\section{REFERENCES}

E Ariga, S., Ito, S., Deji, T., Saze, K., \& Nishizawa. (2012). Determination of Half Value Layers of X-ray equipment Using Computed Radiography Imaging Plates. Physics Medica, 1(1). https://doi.org/doi:10.1016/j.ejmp.20 11.01.001

Fahmi, Arif, K., Firdausi, S., \& Budi, W. S. (2008). Pengaruh Faktor Eksposi pada Pemerikasaan Abdomen terhadap Kualitas Radiograf dan Paparan Radiasi Menggunakan Computed Radiograph, 11(4), 109-118.

G., W., \& Budiantari, C. T. (2005). Optimalisasi Aspek Keselamatan Pada Kalibrasi Pesawat Radioterapi.

Gabriel, J. (1996). Fisika Kedokteran. Denpasar-Bali: Departemen Fisika Universitas Udayana.

Nurdin, W. B. (2015). Fisika Kedokteran Nuklir, Pusat Kajian dan Peningkatan Aktivitas Instruksional LKPP. Makassar: Universitas Hasanuddin.

Palinggi, Y. (2016). Penentuan Nilai Half Value Layer (HVL) Dari Plate Aluminium Dengan Metode Variasi Ketebalan Filter Menggunakan Pesawat Linear Accelerator (LINAC). In Universitas Hasanuddin. Makassar: Universitas Hasanuddin.

Peraturan Pemerintah Republik Indonesia.

Keputusan Menteri Kesehatan

Republik Indonesia Nomor 1250/MENKES/SK/XIII/2009

Tentang Pedoman Kendali Mutu (Quality Control) Peralatan Radiodiagnostik, Pub. L. No. 13 (2009). Indonesia.

Sprawls, P. (1995). Physical Principles of Medical Imaging (2nd ed.). USA: Aspen Publisher.

Sumarni. (2008). Pusat Pendidikan dan Pelatihan Badan Tenaga Nuklir Nasional. In Deteksi dan Pengukuran Radiasi. Jakarta: Pusdiklat-BATAN. Sumarni, T., \& Mart, N. (2000). Energi 
Efektif Sinar-X Radiodiagnostik. In Puslitbang Keselamatan Radiasi dan Biomedik Nuklir. Batan.

Yuniasari, L., Kristiyanti, B., Rozali, B., \& Syawaludin. (2013). Perancangan Perisai Radiasi pada Kepala Sumber untuk Pesawat Radioterapi Eksternal Menggunakan co-60 pada Posisi beam off. Pusat Rekayasa Perangkat Nuklir (PRPN), 7.

Yunita, H. D., Setiawati, E., \& Anam, C. (2014). Evaluation Method Determination Half Value Layer (HVL) Using Multi Purpose Detector (MPD) Barracuda Sinar-X Mobile, 3(2), 113-118. 